\title{
Japan's fast reactor heads for the slow track
}

Tokyo. A year and a half behind schedule, and surrounded by protesters, Japan's multibillion-dollar prototype fast-breeder reactor Monju reached criticality for the first time last week. But it did so amid growing signs that Japan is likely to delay the introduction of commercial breeder reactors, initially planned for 2010 , beyond even its revised target of between 2020 and 2030 .

Construction of Monju was completed in April 1991, at a cost of $¥ 600$ billion (US\$6 billion), and the reactor was scheduled to reach criticality in October 1992. But problems with production of the fuel rods pushed back that date three times. It will still be at least another year before Monju starts producing electricity, and the plant will not reach its full capacity of $280,000 \mathrm{~kW}$ until December 1995.

Japan launched its fast breeder programme several decades ago, at a time of widespread enthusiasm for such reactors. Since then, the United States has abandoned its programme, Britain and Germany have frozen theirs, and France's Superphénix reactor has been plagued with problems (see page 576). But Japan has stuck doggedly to its plans, although with delays.

Nevertheless, in the mid-1980s, Japan put back the target for commercial breeder reactors from 2010 to between 2020 and
2030. Now even the new dates are looking increasingly unlikely; in January, the Federation of Electric Power Companies decided to postpone by several years - to around 2005 - the construction of a demonstration reactor planned to follow Monju.

Growing international concern about Japan's accumulation of the plutonium needed to power breeder reactors could also result in delays. Japan's first nuclear fuel repro-cessing plant is due to begin operation in Rokkasho, a remote village in northern Japan, in 1998. But in February, unnamed officials were quoted in newspaper reports as saying that plans to build a second reprocessing plant for producing plutonium are likely to be postponed by 20 years (from 2010 to 2030 ) to prevent the accumulation of a plutonium surplus.

More recently, officials of the Ministry of International Trade and Industry have been reported as saying the government will have to scale down recycling plans on the grounds that having a major capacity to produce plutonium is a threat to world peace.

Last Saturday (9 April), suspicions of a likely delay were reinforced by a separate report from the Japanese Broadcasting Corporation that the Atomic Energy Commission has decided to postpone construction of the second reprocessing plant. But this will

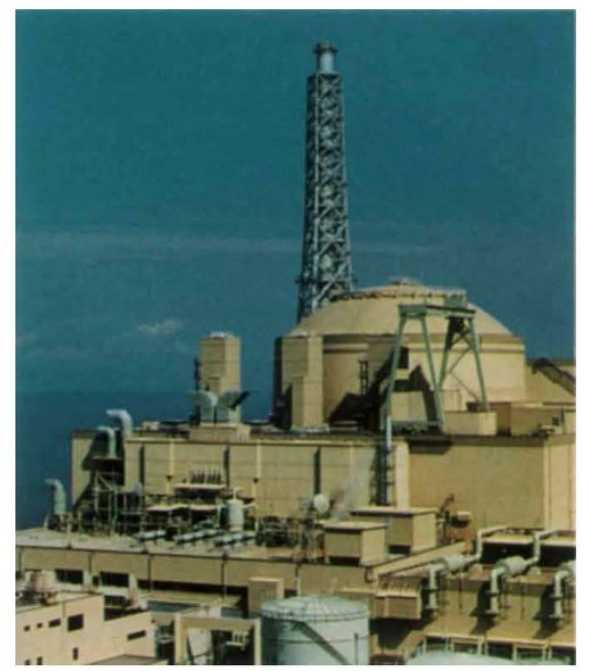

Monju reactor now critical.

not be officially announced until the commission releases its new long-term nuclear power policy this summer.

Officials of the Science and Technology Agency in charge of Monju and nuclear fuel recycling admit that the commission is likely to announce delays on several fronts. They say the target of introducing commercial fast reactors between 2020 and 2030 is "under review".

David Swinbanks

\section{French lab drops US deal over access to DNA bank}

Paris. The researcher at the centre of a dispute over the future of a DNA bank collected from more than 800 French families and based at the Centre d'Etudes du Polymorphisme Humain (CEPH) in Paris (see Nature 368, 175; 1994) was claiming victory last week after the board of CEPH abandoned a proposed deal that would have given Millennium, a Massachusetts-based biotechnology company, exclusive access to the bank.

Philippe Froguel, whose group developed the bank, was fired from CEPH last month, after publicly opposing the proposed agreement. But matters have since been taken out of CEPH's hands by the government, which has set up a commission to decide how to regulate the commercial use of DNA banks.

High among the government's concerns is the threat that foreign companies may gain control of research "made in France"; the scientist heading the commission, Pierre Louisot, is also responsible for protecting France's "scientific heritage" at the biomedical research organization, INSERM(see Nature 367, 587; 1994).

The board of CEPH has now decided, after what is reported to have been a heated debate, to abandon the proposed deal with
Millennium. Froguel says that CEPH has also assured him that he can continue working at the centre until he finds another laboratory, and that he will be able to take a copy of the DNA bank with him when he goes.

Froguel has asked the commission to give him exclusive access to the bank, in collaboration with research groups of his choice, for one or two years before the bank is made publicly available.

Froguel says he is considering a move to the Cochin hospital in Paris. But another possibility would be to set up a laboratory in the United Kingdom.

Meanwhile Hoffmann-La Roche, the Swiss-based pharmaceutical company, has signed a US\$70 million deal with Millennium, to develop therapeutics for obesity and Type II diabetes based on research into the genetics of the diseases. Most of the US\$70 million will pay for research. But Roche will also take an undisclosed equity stake in Millennium, a company set up last year with US\$8.45 million of venture capital.

Roche says that its main interest in the deal is to develop technologies that "open the doors" to other therapeutic areas in the long term. It has already taken a major equity stake in Genentech, in a similar move to buy into know-how.
Under the terms of the deal, Millennium will carry out screening of cDNAs, identify mutant genes in mouse models and isolate disease genes by positional cloning. The company will also work out what the genes do, and design therapeutic agents.

Roche will get exclusive worldwide rights to small molecule therapeutics developed by Millennium. It also gets exclusive rights to antisense, protein, and gene therapies outside North America, while Millennium will retain these rights in North America, subject to Roche's option to co-promote.

Initial plans envisaged that Millennium would have provided access to the DNA banks at CEPH. Indeed, Michael Steinmetz, vice-president and group director for preclinical research of Roche, emphasized the importance of the CEPH DNA bank to the proposed deal with Millennium in a letter written earlier this year to Jean Dausset, the president of CEPH.

Sherry Reynolds, a spokeswoman for Millennium, says it has a "broad strategy" for gaining access to DNA from several groups. The company may also get nonexclusive access to the French bank, she adds, but this will depend on the outcome of the French government commission's discussion, expected in June. Declan Butler 